\title{
Palatability and defense of some tropical infaunal worms: alkylpyrrole sulfamates as deterrents to fish feeding
}

\author{
Cynthia E. Kicklighter ${ }^{1}$, Julia Kubanek ${ }^{1,2}$, Todd Barsby ${ }^{1}$, Mark E. Hay ${ }^{1, *}$ \\ ${ }^{1}$ School of Biology, Georgia Institute of Technology, Atlanta, Georgia 30332-0230, USA \\ ${ }^{2}$ School of Chemistry and Biochemistry, Georgia Institute of Technology, Atlanta, Georgia 30332-0400, USA
}

\begin{abstract}
Numerous studies have investigated chemical defenses among sessile species growing on hard substrates, but few have addressed this for mobile species in soft-sediment communities. We investigated the palatability and potential chemical defenses of 11 worm species from soft-sediment systems in southern Florida, USA. Three species were unpalatable to the bluehead wrasse Thalassoma bifasciatum. The polychaete Cirriformia tentaculata and the hemichordate Ptychodera bahamensis were uniformly unpalatable. For the polychaete Eupolymnia crassicornis, the exposed tentacles were unpalatable, but the body, which remains protected in a deeply buried tube, was palatable. These unpalatable worms were chemically defended; extracts of $C$. tentaculata, $P$. bahamensis, and the tentacles of $E$. crassicornis deterred fish feeding. For $C$. tentaculata, bioassay-guided fractionation demonstrated that a mixture of 3 closely related alkylpyrrole sulfamates deterred fish at naturally occurring concentrations (2-n-hexylpyrrole sulfamate [1.6\% of worm dry mass], 2-n-heptylpyrrole sulfamate [3.1\% dry mass], and 2-n-octylpyrrole sulfamate [0.8\% dry mass]). This appears to be the first documentation of characterized natural products defending a marine worm from consumers. For $P$. bahamensis and the tentacles of E. crassicornis, deterrent effects of crude extracts decomposed before specific compounds could be identified.
\end{abstract}

KEY WORDS: Chemical defense - Marine worms - Cirriformia tentaculata - Soft-sediment . 2-n-hexylpyrrole $\cdot 2$ - $n$-heptylpyrrole $\cdot 2$-n-octylpyrrole

\section{INTRODUCTION}

Numerous studies have demonstrated chemical defenses among sessile, hard-substrate species such as seaweeds (reviewed in: Hay \& Fenical 1988, Hay 1997, Paul et al. 2001), sponges (reviewed in Paul 1992, Pawlik 1993, Pawlik et al. 1995), ascidians (reviewed in Pawlik 1993, Pisut \& Pawlik 2002), soft and gorgonian corals (reviewed in Paul 1992, O'Neal \& Pawlik 2002), and even larvae of many of these species (Lindquist \& Hay 1996). These investigations indicated that chemical defenses influence the distribution and behavior of prey because chemically defended species can persist as overt members of habitats where predation risk is high. In contrast, undefended, palatable species persist by escaping in space or time. They live in less heavily impacted habitats (e.g. reef flats, mangroves), refuge in cracks and crevices, or are active during periods (e.g. night) when their consumers are inactive (Dunlap \& Pawlik 1996, Lindquist \& Hay 1996, Hay 1997).

In contrast to the many studies of sessile species from hard substrate habitats, few studies have investigated the palatability or chemical defenses of mobile species from soft-sediment habitats. Unusual, often brominated, secondary metabolites are well known and common among infaunal invertebrates (e.g. Woodin et 
al. 1987, Goerke et al. 1991, Fielman et al. 1999). However, the ecological function of these metabolites is largely uninvestigated. Some of these metabolites can affect larval settlement (Woodin et al. 1997), and the metabolites have been hypothesized to function as defenses against consumers (Yoon et al. 1994, Fielman \& Targett 1995, Fielman et al. 1999, Cowart et al. 2000); however, this has rarely been experimentally evaluated by directly assaying the effects of these metabolites on consumer feeding. In the one study that has addressed both the palatability of numerous worms and the role of these brominated secondary metabolites as defenses, one tribromopyrrole strongly deterred fish, but not crab, feeding, while 5 common bromophenols did not deter consumers (see Kicklighter et al. in press). A recent investigation also demonstrated that the crude extract from an annelid worm deterred consumer feeding, but the active metabolites were not identified (Gaston \& Slattery 2002). In the only available survey of both palatability and possible chemical defenses of marine worms, 19 of 20 species of worms from Georgia and North Carolina, USA, were found to be palatable to sympatric fishes and a crab; only the hemichordate Saccoglossus kowalevskii was chemically defended against fishes, but even this species was palatable to a local crab (Kicklighter et al. in press).

Whether this low frequency of unpalatable, and chemically defended, invertebrates in soft-substrate communities is the exception or the norm is unclear given the paucity of available studies. As an initial contrast to the above temperate study, we used a common generalist predator, the bluehead wrasse Thalassoma bifasciatum, to examine the palatability and chemical defense of 11 species of annelid or hemichordate worms found in soft-substrate habitats of southern Florida.

\section{MATERIALS AND METHODS}

Worms were collected between July and August 2002 from intertidal and subtidal soft-sediment habitats around Key Largo, Florida (Rodriguez Key: 250 $08^{\prime} \mathrm{N}$, $80^{\circ} 25^{\prime} \mathrm{W}$; Pickles Reef: $24^{\circ} 60^{\prime} \mathrm{N}, 80^{\circ} 24^{\prime} \mathrm{W}$; Blackwater Sound: $25^{\circ} 08^{\prime} \mathrm{N}, 80^{\circ} 25^{\prime} \mathrm{W}$; mile marker 110: $25^{\circ} 11^{\prime} \mathrm{N}$, $\left.80^{\circ} 25^{\prime} \mathrm{W}\right)$, Estero Bay, Bonita Springs, Florida $\left(26^{\circ} 27^{\prime} \mathrm{N}\right.$, $\left.81^{\circ} 56^{\prime} \mathrm{W}\right)$, and Clam Pass, Naples, Florida $\left(26^{\circ} 14^{\prime} \mathrm{N}\right.$, $\left.81^{\circ} 48^{\prime} \mathrm{W}\right)$. The collections included worms from the Phylum Hemichordata (Pytcodera bahamensis) and the following polychaete annelid families: Capitellidae (Dasybranchus lumbricoides, Heteromastus sp.), Cirratulidae (Cirriformia tentaculata), Eunicidae (Marphysa sanguinea), Maldanidae (Abyssoclymene sp., Clymenella sp.), Nereididae (Websterinereis sp.), Orbiniidae (Haploscoloplos sp.), Spionidae (Laonice sp.), and Terebellidae (Eupolymnia crassicornis).
To assess worm palatability, we fed worms to the bluehead wrasse Thalassoma bifasciatum, a generalist fish that feeds mainly on small benthic prey (Feddern 1965). T. bifasciatum is common on coral reefs, in back reef rubble and sand zones, and often along the margins of seagrass beds and sandy areas where these habitats are intermixed with patches of hard, or gorgonian corals. Thus, the fish will commonly co-occur with worms we collected from sandy and rubble areas near structures, but they would be less frequent consumers of worms we collected from intertidal sand flats, subtidal sand plains, or seagrass beds without adjacent structures. However, because feeding preferences of bluehead wrasse commonly parallel preferences of other generalist consumers (see Lindquist \& Hay 1996, McClintock et al. 1996, Bullard \& Hay 2002a, Burns et al. 2003), and because this wrasse has commonly been used as a model, generalist consumer in other investigations of invertebrate chemical defenses (e.g. Pawlik et al. 1995, Lindquist \& Hay 1996, Kubanek et al. 2002, Pisut \& Pawlik 2002), we used this species for our bioassays of palatability.

Feeding assays were conducted either at NOAA's National Undersea Research Center in Key Largo, Florida, or at the Georgia Institute of Technology's marine facility on Skidaway Island, Georgia. Individual fish were kept in 2.1 or 2.41 containers in recirculating seawater systems. To assure that consumers were not feeding indiscriminately due to unusual hunger levels, consumers were fed frozen brine shrimp (San Francisco Bay Brand) to satiation each morning. Feeding assays, using worms or worm extracts were conducted about $1 \mathrm{~h}$ after this initial morning feeding. Fish were offered a palatable control food (a brine shrimp). If this was consumed, fish were then offered fresh or thawed worm portions (worms collected from Estero Bay and Clam Pass, Florida, were frozen and taken back to Georgia for feeding assays because facilities for keeping fish were unavailable at these collection sites). For worms that had morphologically distinct body parts, each body part was offered to fish separately. If the consumer ate the worm offering (even if it was spit out first), it was scored as accepted. If the consumer spit out the worm portion and made no attempt to try it again within about $30 \mathrm{~s}$, the replicate was scored as rejected. A fish that rejected the worm was then offered a second brine shrimp to ensure it did not reject the worm because the fish was satiated and not willing to feed on any food. Any fish that did not consume either the initial or second brine shrimp was excluded from consideration. It was uncommon for fish to reject the second control (this occurred 7 times out of 553 portions offered, i.e. $1.3 \%$ of offerings). Fisher's Exact Test was used to assess feeding on control food versus worm portions or foods containing chemical extracts. 
To investigate whether rejected worms were chemically defended, crude extracts from the worm of interest were mixed into a squid-based food and fed to Thalassoma bifasciatum. Feeding on these treatment foods was compared to feeding on a palatable control consisting of the squid-based food without added extract (methods of Lindquist \& Hay 1996). We determined the caloric value of each worm species tested for chemical deterrence, so we could match the value of our artificial squid-based food to that of the worm being investigated. The caloric content (calories $\mathrm{g}^{-1}$ ) of Eupolymnia crassicornis $(\mathrm{n}=4)$, Ptychodera bahamensis $(\mathrm{n}=6)$, Cirriformia tentaculata $(\mathrm{n}=4)$, and of homogenized squid mantle $(\mathrm{n}=6)$ was determined by bomb calorimetry of 0.3 to $0.5 \mathrm{~g}$ dry mass of lyophilized tissue in a Parr 1425 Semimicro bomb calorimeter (Parr Instrument). Values were converted to calories $\mathrm{ml}^{-1}$ of tissue based on a dry mass $\mathrm{vol}^{-1}$ conversion for each species and for squid-based food. By mixing different ratios of squid and water, we made test foods that matched the caloric value per $\mathrm{ml}$ of the particular worm from which a chemical extract had been acquired.

The squid-based food was made by reconstituting lyophilized homogenated squid mantle with $0.03 \mathrm{~g}$ sodium alginate per $\mathrm{ml}$ of squid. To incorporate the extracts of compounds into the squid paste, an appropriate aliquot of extract or compound was solubilized in ethanol and transferred to a $2.0 \mathrm{ml}$ microcentrifuge tube. Squid paste that mimicked the nutritional value of the worm was then added and mixed to ensure that the extract was evenly dispersed. The squid food 'paste' was drawn up into a $50 \mu \mathrm{l}$ pipette and extruded into a $0.25 \mathrm{M}$ calcium chloride solution, which caused the paste to harden. After about $30 \mathrm{~s}$, the squid 'noodle' was removed from the calcium chloride and cut into small pieces. Consumption of squid paste pellets without added extract (but with an equal volume of ethanol added) was compared to that of squid-paste containing extract.

Extracts of unpalatable worms were added to treatment food at either 1-, 3-, 4-, or 5-times volumetric concentration at which extracts were isolated. Some extracts were added at concentrations greater than natural because we suspected that the compound was volatile and was being lost during the separation and drying process (i.e. Ptychodera bahamensis hexanes extract) or because the extract was losing deterrence, likely due to decomposition of active compounds. Once a deterrent compound was identified, we then determined its true concentration in the worm and retested it at this natural concentration.

Cirriformia tentaculata, Ptychodera bahamensis, and the tentacles of Eupolymnia crassicornis were unpalatable, suggesting they might be chemically defended from consumers. To acquire crude extracts from Cirri- formia tentaculata, tissues were extracted twice with $100 \%$ acetone, $100 \%$ methanol, and $100 \%$ ethyl acetate (each volume was equivalent to approximately 2 times the volume of worm tissue). Extracts were combined, filtered to remove solids, and solvent was removed with a rotary evaporator. This crude extract was then tested in feeding assays. Because it deterred feeding, the extract was partitioned between 9:1 methanol:water versus hexanes. The hexanes layer was removed and bioassayed. The methanol was then removed from the methanol:water fraction using a rotary evaporator and the resulting water was partitioned against ethyl acetate and bioassays were run separately on the ethyl acetate and water partitions. Only the ethyl acetate fraction was deterrent, so it was separated on a $10 \mathrm{~g} \mathrm{C}_{18}$ Vac 35cc reversed-phase seppak (Waters) using the following series of solvents: 50:50 methanol:water, 80:20 methanol:water, 90:10 methanol:water, $100 \%$ methanol and then $100 \%$ ethyl acetate (the eluants of these last 2 mobile phases were combined). Fractions were bioassayed separately. Only the 80:20 methanol:water fraction was deterrent, so nuclear magnetic resonance (NMR) spectroscopy was used to elucidate the structures of the metabolites in this active fraction (Barsby et al. 2003).

Once the deterrent metabolites had been identified, we used Liquid Chromatography/Mass Spectrometry (LC/MS) (Waters Alliance 2695 Separations Module, 2996 PDA coupled to a Waters Micromass ZQ 2000 ESI mass spectrometer) to quantify their natural concentration in Cirriformia tentaculata. Specimens for this procedure were collected in December 2002 from Key Largo, Florida, brought back to the laboratory and kept alive in an aquarium with sediments that were from the site of collection, but with no additional food, until their use in January 2003. The metabolites were quantified from 9 individual worms by extracting each worm 4 times with 1 to $2 \mathrm{ml}$ methanol. Extracts were removed after centrifugation to eliminate particles. The worm tissues remaining after extractions were dried at $60^{\circ} \mathrm{C}$ for $72 \mathrm{~h}$ to determine dry weight. All 4 extracts from each worm were combined and solvents removed in a speedvac. The dried extract from each worm was dissolved in $1 \mathrm{ml}$ of methanol and $20 \mu \mathrm{l}$ of this was subjected to LC/MS analysis. Metabolite concentrations were calculated using a calibration curve based on a $20 \mu$ injection of either 5 (2-n-hexylpyrrole sulfamate) or 7 (2-nheptylpyrrole sulfamate, 2-n-octylpyrrole sulfamate) standards. Once we quantified the natural concentrations of the metabolites in the worms, we conducted feeding assays using natural concentrations of the 3 alkylpyrrole sulfamates (the 3 compounds were tested as a mixture because we could not adequately separate them via HPLC). 
For Eupolymnia crassicornis, chemical procedures differed from those for Cirriformia tentaculata because we performed chemical analyses of E. crassicornis first, and then modified our procedures for C. tentaculata based on problems of chemical instability found for extracts of E. crassicornis. Freshly collected E. crassicornis tentacles were placed in $100 \%$ acetone, clipped into small pieces, and extracted twice in a volume of acetone equal to approximately 2 times the volume of worm tissue. The extract was filtered, and solvent was removed on a rotary evaporator. The crude extract deterred feeding at natural volumetric concentration, so it was further partitioned based on a modified Kupchan et al. (1975) scheme (hexanes, dichloromethane, ethyl acetate, butanol, and water). These extracts were bioassayed separately.

For Ptychodera bahamensis, we used different chemical methods than for Eupolymnia crassicornis and Cirriformia tentaculata because most of the known chemistry from hemichordates is volatile and we wanted to use methods that would minimize loss of volatiles. Freshly collected worms were placed in methanol equivalent to approximately 2 times the volume of the worms. The worms were then cut into small pieces with scissors, distilled water (volume equivalent to the methanol added) was added, and the vial was shaken. An equal volume of hexanes was then added and the vial was shaken several times. The hexanes layer was drawn off and saved. The hexanes procedure was repeated 2 more times to ensure efficient extraction. Hexanes extracts were combined and concentrated by drying under a stream of nitrogen (keeping the vial on ice). The methanol/water extract was filtered to remove particulates and dried on a speedvac. Both the hexanes and methanol/ water extracts were deterrent at natural concentrations. We pursued the deterrence of the hexanes via normal phase chromatography. We pursued the deterrence of the methanol/water extract by removing the methanol with a rotary evaporator and partitioning the extract between water and ethyl acetate. Both partitions were deterrent. The water fraction was separated into 7 fractions using a $10 \mathrm{~g} \quad \mathrm{C}_{18}$ Vac 35cc reversed-phase sep-pak (Waters), starting with $100 \%$ water and increasing the concentration of methanol by $10 \%$ up to $50: 50$ methanol:water and then flushing with $100 \%$ methanol. Each of the 7 fractions was separately evaluated in feeding assays. We also recombined aliquots of each fraction to reconstitute the initial water fraction and retested its effect on feeding.
The deterrent ethyl acetate fraction from the water: ethyl acetate partition was separated on a reversed phase silica TLC plate (200 $\mu$ m thick, VWR) using 80:20 methanol:water as the solvent. This process produced 7 fractions, 2 adjacent fractions were deterrent. These were recombined and further purified by reversed phase sep-pak using 70:30 methanol:water as the solvent. This produced 5 fractions, one of which was deterrent. We tried to further purify this fraction by reversed phase HPLC, but could not maintain deterrence. Loss of activity was likely due to decomposition of the active compound(s). As fractions were collected, they developed a brownish color, suggesting oxidation. Lack of fresh material prevented pursuing this.

\section{RESULTS}

Three of 11 species were at least in part unpalatable to the bluehead wrasse Thalassoma bifasciatum (Fig. 1). Ptychodera bahamensis and Cirriformia tentaculata were entirely unpalatable. Fish rejected the tentacles of Eupolymnia crassicornis, but its body was palatable. Abyssoclymene sp., Clymenella sp., Dasybranchus lumbricoides, Haploscoloplos sp., Heteromastus sp., Laonice sp., Marphysa sanguinea, and Websterinereis sp. were readily consumed. Caloric content (calories $\mathrm{ml}^{-1} \pm 1 \mathrm{SE}$ ) of rejected worms and our control food were: C. tentaculata $(832 \pm 51), P$. bahamensis $(404 \pm$ $30)$, tentacles of E. crassicornis (809 \pm 26$)$, and squid homogenate $(834 \pm 11)$.

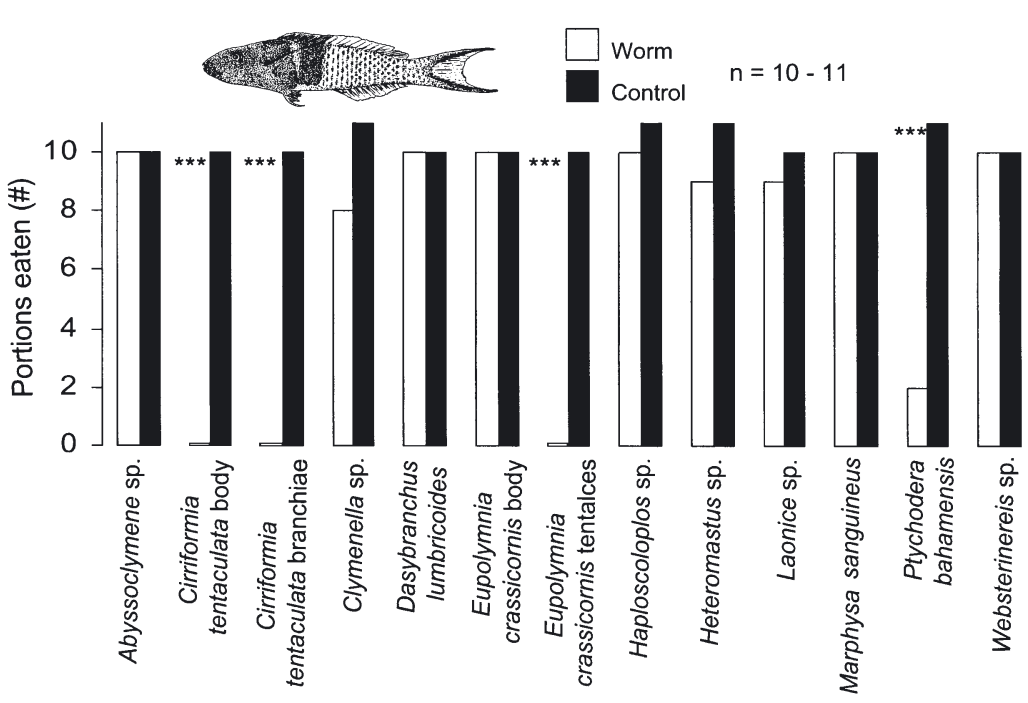

Fig. 1. Palatability of worms or worm parts to bluehead wrasse Thalassoma bifaciatum. Each separate fish was offered brine shrimp (control food) followed by worm tissue and the food scored as accepted or rejected. $* * * p \leq 0.001$ by the Fisher's Exact Test 
The crude extract from Cirriformia tentaculata strongly deterred feeding (Fig. 2A) at natural volumetric concentration. When this extract was partitioned among hexanes, ethyl acetate, and water, only the ethyl acetate-soluble fraction was deterrent (Fig. 2B). Further separation via reversed phase chromato-

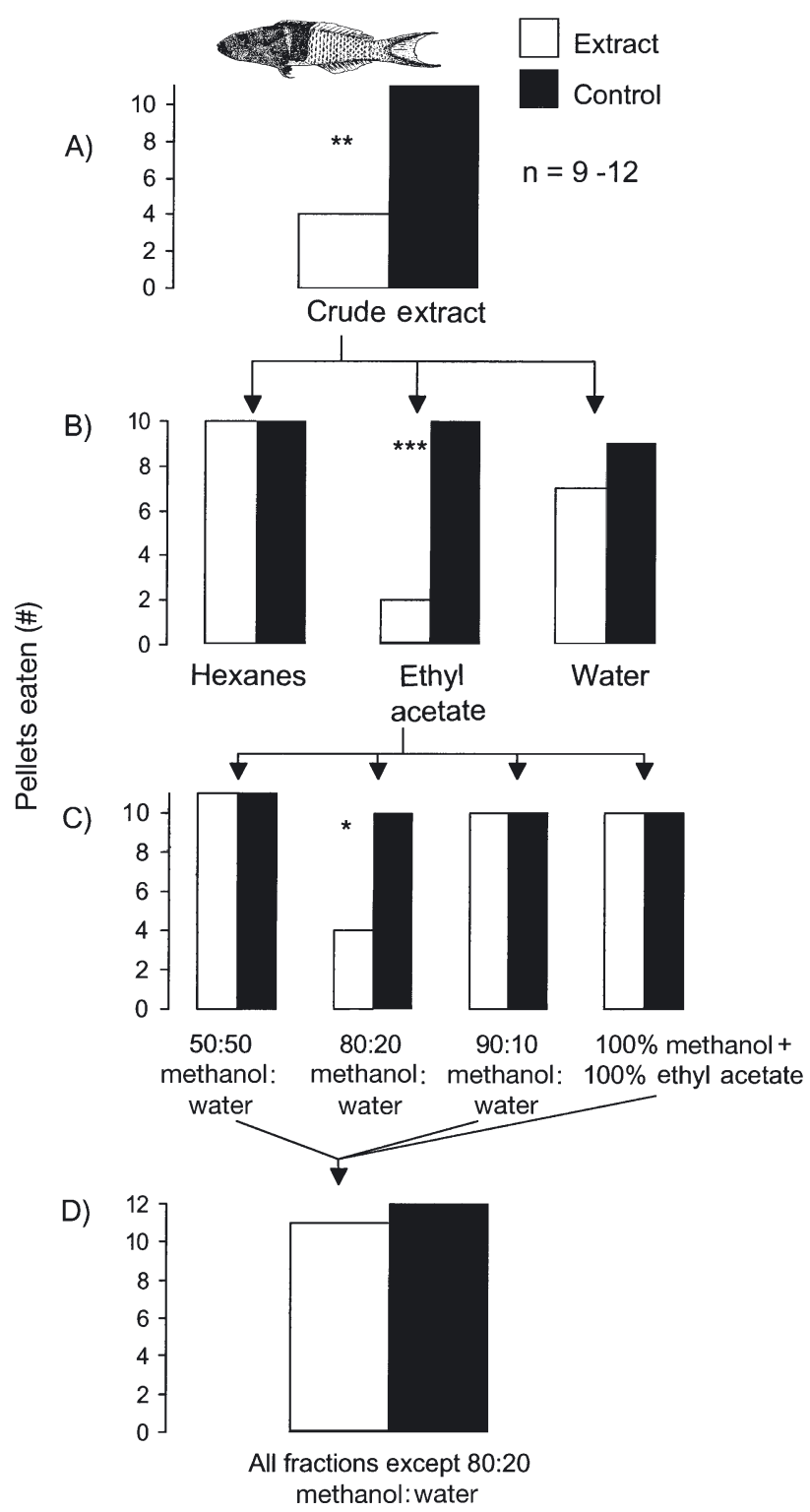

Fig. 2. Bioassay-guided fractionation of Cirriformia tentaculata extracts fed to bluehead wrasse. Assays were run at $4 \times$ natural volumetric concentration unless otherwise noted. Each separate fish was offered a control squid pellet as food (without extract added) followed by a squid pellet treated with extract, and then food was scored as accepted or rejected. Palatability assays of (A) crude extract ( $3 \times$ natural concentration), (B) hexanes, ethyl acetate and water-soluble partitions, (C) fractions from ethyl acetate separation, and (D) all fractions except the deterrent 80:20 methanol water fraction. $* \mathrm{p} \leq 0.05, * * \mathrm{p} \leq 0.01, * * * \mathrm{p} \leq 0.001$ by the Fisher's Exact Test graphy produced 4 fractions, only 1 of which (80:20 methanol:water) was deterrent (Fig. 2C). When the non-deterrent fractions from the reversed phase separation were recombined and assayed, this recombined extract had no effect on feeding (Fig. 2D), suggesting that the 80:20 methanol:water fraction contained all the deterrent metabolites. Analyses of the deterrent fraction by LC/MS and by both ${ }^{1} \mathrm{H}$ and ${ }^{13} \mathrm{C}$ NMR spectroscopy indicated a mixture of 3 related pyrrole sulfamates, with no other metabolites being apparent (Barsby et al. 2003). The structures of these pyrroles (2-n-hexylpyrrole sulfamate, 2-n-heptylpyrrole sulfamate, and 2-n-octylpyrrole sulfamate) are shown in Fig. 3. LC/MS quantification of the metabolites for 9 individual worms determined the \% dry mass $\pm 1 \mathrm{SE}$ of 2-n-hexylpyrrole sulfamate, $2-n$-heptylpyrrole sulfamate, and 2-n-octylpyrrole sulfamate to be $1.6 \pm 0.8 \%$, $3.1 \pm 1.4 \%$ and $0.8 \pm 0.4 \%$, respectively. Natural concentrations of a mixture of these metabolites strongly deterred feeding by bluehead wrasse (Fig. 3).

The crude extract of Eupolymnia crassicornis tentacles strongly deterred fish feeding at natural concentration (9 treatment pellets rejected, 9 control pellets consumed; $\mathrm{p}<0.001$, Fisher's Exact Test). When this extract was partitioned among hexanes, dichloromethane, ethyl acetate, butanol, and water, only the dichloromethane partition deterred feeding (9 of 11 treatment pellets rejected, 11 control pellets consumed; $\mathrm{p}<0.001$, Fisher's Exact Test). We were unable to separate and identify the deterrent metabolites in this fraction due to repeated loss of deterrence with further purification.

From Ptychodera bahamensis, both the hexanes and methanol/water partitions deterred feeding at natural

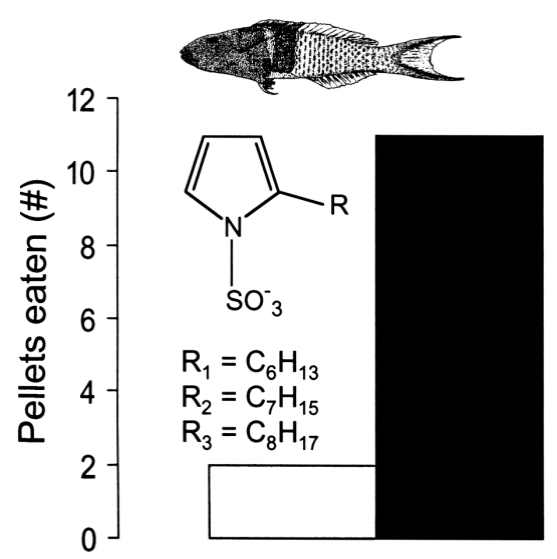

Fig. 3. Effects of a natural concentration mixture of 2-nhexylpyrrole sulfamate $(1.6 \pm 0.8 \%$ of food dry mass $), 2-n-$ heptylpyrrole sulfamate $(3.1 \pm 1.4 \%)$, and 2 - $n$-octylpyrrole sulfamate $(0.8 \pm 0.4 \%)$ from Cirriformia tentaculata on feeding by bluehead wrasse. Methods, symbols, and analysis as described in Fig. 2 
concentrations (hexanes $=7$ of 15 treatment pellets rejected, 15 control pellets consumed; $\mathrm{p}=0.006$; methanol/water $=6$ of 10 treatment pellets rejected, 10 controls consumed; $\mathrm{p}=0.011$, Fisher's Exact Tests). Further chemical investigation of the hexanes partition was unsuccessful due to loss of activity with further separation. When the deterrent methanol/water fraction was partitioned between water and ethyl acetate, both were deterrent (for both assays, 7 of 10 treatment pellets rejected, 10 control pellets consumed; $\mathrm{p}=0.003$, Fisher's Exact Tests). The water-soluble fraction was partitioned into 7 fractions via reversed phase chromatography, none of which deterred feeding $(\mathrm{p}>0.999$ for all contrasts). However, when aliquots of all these fractions were recombined, they regained deterrence (8 of 10 treatment pellets rejected, 10 control pellets consumed; $\mathrm{p}<0.001$ ), suggesting that deterrence was due to additive or synergistic effects. Additional attempts at separation and purification resulted in loss of activity. When the deterrent ethyl acetate-soluble fraction was separated into 7 fractions by reversed phase chromatography, 2 adjacent fractions (4 and 5) deterred fish feeding ( 6 and 5 of 10 treatment pellets rejected, respectively, all controls eaten; $\mathrm{p}=0.011$ and $p=0.033$, respectively). These deterrent fractions were combined and separated into 5 fractions via reversed phase chromatography; 1 fraction (3) was deterrent (6 of 10 treatment pellets rejected, 10 controls eaten; $\mathrm{p}=0.011$ ). Further separation of this fraction resulted in loss of deterrence, so the active compounds could not be identified.

\section{DISCUSSION}

Of the 11 worm species we assayed, 8 were readily eaten by the bluehead wrasse Thalassoma bifasciatum; only 3 species (Cirriformia tentaculata, Ptychodera bahamensis, and Eupolymnia crassicornis) were unpalatable (Fig. 1). For E. crassicornis, unpalatability was restricted to the tentacles; the body was palatable. Thus, 3 of the 11 tropical species we investigated were unpalatable to a local fish. A similar investigation of temperate worms found only 1 of 20 species to be unpalatable to local fishes (Kicklighter et al. in press). This difference is not statistically significant $(p=0.115$, Fisher's Exact Test). The low frequency of unpalatability in both locations suggests that chemical defenses may be uncommon among mobile infaunal worms and that larger sample sizes will be needed to reliably assess possible differences in palatability or chemical defenses between latitudes.

Effects of crude extracts on fish feeding suggested that each of our 3 distasteful species were defended chemically; however, we were able to determine the specific metabolites responsible for deterrence only in the case of Cirriformia tentaculata. This species is defended by 3 related metabolites that have a combined concentration of $5.5 \%$ of worm dry mass (2-n-hexylpyrrole sulfamate [as $1.6 \pm 0.8 \%$ of worm dry mass], $2-n$ heptylpyrrole sulfamate [3.1 $\pm 1.4 \%$ dry mass], and 2$n$-octylpyrrole sulfamate [ $0.8 \pm 0.4 \%$ dry mass]). Natural concentrations of these metabolites strongly suppressed fish feeding (Fig. 3). A brominated pyrrole sulfamate related to those we found is also reported from the marine hemichordate Saccoglossus kowalevskii (Fielman \& Targett 1995), but its ecological role was not assessed. To our knowledge, this is the first demonstration that alkylpyrrole sulfamates can serve as chemical defenses against consumers and is the first characterized chemical defense from a marine annelid.

Although soft-substrate invertebrates commonly produce impressive concentrations of organic, often halogenated, secondary metabolites (Higa et al. 1980, Goerke et al. 1991, Fielman \& Targett 1995) and these metabolites have commonly been quantified and assumed to play roles as chemical defenses against consumers (Woodin et al. 1987, Yoon et al. 1994, Fielman \& Targett 1995, Fielman et al. 1999, Cowart et al. 2000), direct tests of 5 brominated phenols and 1 tribromopyrrole found that only the tribromopyrrole deterred consumers (Kicklighter et al. in press). Additionally, numerous species of worms that produce unusual, commonly brominated metabolites are readily eaten by co-occurring consumers (Giray \& King 1997, Kicklighter et al. in press). These patterns indicate that ecological activity cannot be predicted from general chemical characteristics alone (e.g. halogenated organic, phenolic, etc.) and that chemical and ecological investigations will need to be closely coupled to determine the ecological roles of different secondary metabolites. This is also the case for other marine groups producing diverse arrays of secondary metabolites (e.g. Hay \& Fenical 1988, Hay \& Steinberg 1992, Pawlik 1993, McClintock \& Baker 2001). To date, the specific alkylpyrrole sulfamates studied here and the 2,3,4-tribromopyrrole tested by Kicklighter et al. (in press) are the only chemically characterized worm metabolites that have been experimentally demonstrated to function as chemical defenses against consumers. However, our assays with Ptychodera bahamensis and Eupolymnia crassicornis indicate that other species are also chemically defended-possibly by less stable or more volatile metabolites or by additive or synergistic effects of multiple metabolites - as is suggested by the feeding patterns shown for the water-soluble extracts from $P$. bahamensis.

The palatability of the worms we investigated appears to be related to their lifestyle and exposure to epibenthic predators. Cirriformia tentaculata lives near 
the sediment surface (about $6 \mathrm{~cm}$ deep), protrudes its branchiae above the sediments to respire, and is easy to locate and collect due to its bright red coloration, which may be advertising its distastefulness. In contrast, the palatable body of Eupolymnia crassicornis is protected in a tube that is 10 to $20 \mathrm{~cm}$ below the sediment surface. Only its feeding tentacles are on the sediment surface and exposed to epibenthic consumers, and it is only this portion of its body that is unpalatable and chemically defended. The unpalatable hemichordate Ptychodera bahamensis lives buried beneath sediments, but it commonly occurs in sandy areas adjacent to shallow coral reefs, where consumer pressure is high (Dunlap \& Pawlik 1996, Hay 1997, Bullard \& Hay $2002 b)$ and where heavy seas may uncover and dislodge this worm during storms. While we were collecting $P$. bahamensis, bluehead wrasse and slippery dicks Halichoeres bivittatus commonly bit at specimens we exposed, but rarely consumed them.

In contrast to the patterns for unpalatable species, most palatable species (Abyssoclymene sp., Clymenella sp., Dasybranchus lumbricoides, Haploscoloplos sp., Heteromastus sp., Marphysa sanguinea, and Websterinereis sp.) were not normally exposed above the sediment surface. They tended to burrow deeply or live in tubes buried in the sediments. Thus, they live cryptically and are rarely exposed to epibenthic consumers. Laonice sp. is the only palatable species in our study that did not follow this general trend. It lives and feeds near the sediment surface. This species was collected from intertidal sediments in a very shallow lagoon, which might serve as a spatial refuge from many consumers. However, we did not directly assess this possibility.

Among-species differences in palatability of the worms we investigated can be explained by chemical deterrence. In Eupolymnia crassicornis, a dichloromethane-soluble extract was responsible for the distastefulness of the tentacles. Gaston \& Slattery (2002) also found deterrence in a crude extract of the tentacles of E. crassicornis from Belize, but did not pursue the identity of the chemistry. We repeatedly tried to purify and identify the deterrent metabolites from $E$. crassicornis, but were unsuccessful due to loss of activity following additional separation procedures. This was true for individuals collected from Florida, the Bahamas, and Panama, suggesting that these populations all contain deterrent, but unstable compound(s).

Ptychodera bahamensis appeared to be defended by more than one metabolite, as hexanes, ethyl acetate, and water-soluble extracts each deterred feeding. Further purifications of these fractions also resulted in loss of activity.

Cirriformia tentaculata was chemically defended by a family of pyrrole sulfamates, which differ only in the length of an attached alkane chain (Fig. 3). These compounds were too similar to be effectively separated by HPLC; we were thus unable to bioassay them separately, but in combination, they were effective feeding deterrents. These pyrrole sulfamates are novel compounds and, to our knowledge, this is the first study to experimentally demonstrate a structurally defined chemical deterrent in a marine annelid. The critical role these metabolites may play in allowing this worm to live near the sediment surface is supported by the worm's large allocation ( $>5 \%$ of its dry mass) to these metabolites.

Just as chemical deterrents allow seaweeds and sponges to persist overtly on coral reefs, they may enable unpalatable worms to increase feeding efficiency by allowing greater temporal and spatial access to foods being deposited onto sediment surfaces. Because the tentacles of Eupolymnia crassicornis deter attack via chemical defense, they may be free to forage more continuously and to greater distances ( $>1 \mathrm{~m}$ ) from the refuge or the tube. Similarly, Cirriformia tentaculata may be free to live more shallowly within the sediments than many other species, so that its branchiae can protrude up into the water column for respiration, and therefore its palps can deposit feed on the surface. In addition, through the combination of a cryptic lifestyle and chemical deterrents Ptychodera bahamensis can persist along the edges of reefs where predation is potentially very high. In contrast, most palatable species appear to be restricted to more cryptic lifestyles. Their susceptibility to consumers appears to limit them to using the deeper sediments where mobile infauna appear to escape attack by most epibenthic consumers (Virnstein 1977, 1979); however, this also constrains foraging on new inputs of food at the sediment surface. Thus, chemical defenses may play critical roles in allowing some species to increase their use of more productive foraging habitats, and these advantages might offset the costs, if any, of chemical defenses.

Acknowledgements. We thank D. Burkepile, A. Chequer, J. Godeke-Kicklighter, K. Hay, B. Kicklighter, C. Kicklighter, J. Kicklighter, E. Prince, and B. Woodson for help with collections. We thank A. Hollebone and J. Long for animal maintenance and K. Hollebone for the Thalassoma bifasciatum drawing. We are grateful to the staff of the National Undersea Research Center for their cooperation. Funding for this project was provided by National Science Foundation, predoctoral and Integrative Graduate Education and Research Traineeship fellowships to C.E.K. and by the Harry and Linda Teasley Endowment to the Georgia Institute of Technology.

\section{LITERATURE CITED}

Barsby T, Kicklighter CE, Hay ME, Sullards MC, Kubanek J (2003) Defensive 2-n-alkylpyrrole sulfamates from the marine annelid Cirriformia tentaculata [Polychaeta: Cir- 
ratulidae]. J Nat Prod 66:1110-1112

Bullard SB, Hay ME (2002a) Palatability of marine macroholoplankton: nematocysts, nutritional quality, and chemistry as defenses against consumers. Limnol Oceanogr 47 : 1456-1467

Bullard SB, Hay ME (2002b) Plankton tethering to assess spatial patterns of predation risk over a coral reef and seagrass bed. Mar Ecol Prog Ser 225:17-28

Burns E, Ifrach I, Carmeli S, Pawlik JR, Ilan M (2003) Comparison of anti-predatory defenses of Red Sea and Caribbean sponges. I. Chemical defense. Mar Ecol Prog Ser 252:105-114

Cowart JD, Fielman KT, Woodin SA, Lincoln DE (2000) Halogenated metabolites in two marine polychaetes and their planktotrophic and lecithotrophic larvae. Mar Biol 136: 993-1002

Dunlap M, Pawlik JR (1996) Video monitored predation by Caribbean reef fishes on an array of mangrove and reef sponges. Mar Biol 126:117-123

Feddern HA (1965) The spawning, growth, and general behavior of the bluehead wrasse, Thalassoma bifasciatum (Pisces: Labridae). Bull Mar Sci 15:896-941

Fielman KT, Targett NM (1995) Variation of 2,3,4-tribromopyrrole and its sodium sulfamate salt in the hemichordate Saccoglossus kowalevskii. Mar Ecol Prog Ser 116: 125-136

Fielman KT, Woodin SW, Walla MD, Lincoln DE (1999) Widespread occurrence of natural halogenated organics among temperate marine infauna. Mar Ecol Prog Ser 181:1-12

Gaston GR, Slattery M (2002) Ecological function of chemical deterrents in a tropical polychaete, Eupolymnia crassicornis (Annelida, Terebellidae), in Belize. Bull Mar Sci 70: 891-897

Giray C, King GM (1997) Predator deterrence and 2,4-dibromophenol conservation by the enteropneusts Saccoglossus bromophenolosus and Protoglossus graveolens. Mar Ecol Prog Ser 159:229-238

Goerke H, Emrich R, Weber K, Duchene J (1991) Concentrations and localization of brominated metabolites in the genus Thelepus (Polychaeta: Terebellidae). Comp Biochem Physiol B 99B:203-206

Hay ME (1997) The ecology and evolution of seaweedherbivore interactions on coral reefs. Coral Reefs 16:67-76

Hay ME, Fenical W (1988) Marine plant-herbivore interactions - the ecology of chemical defense. Annu Rev Ecol Syst 19:111-145

Hay ME, Steinberg PD (1992) The chemical ecology of plantherbivore interactions in marine versus terrestrial communities. In: Rosenthal J, Berenbaum M (eds) Herbivores: their interaction with secondary metabolites, evolutionary and ecological processes. Academic Press, San Diego, CA, p 371-413

Higa T, Fujiyama T, Scheuer PJ (1980) Halogenated phenol and indole constituents of acorn worms. Comp Biochem

Editorial responsibility: Joseph Pawlik (Contributing Editor), Wilmington, North Carolina, USA
Physiol B 65B:525-530

Kicklighter CE, Kubanek J, Hay ME (in press) Do brominated natural products defend marine worms from consumers? Some do, most don't. Limnol Oceanogr

Kubanek J, Whalen KE, Engel S, Kelly SR, Henkel TP, Fenical W, Pawlik JR (2002) Multiple defensive roles for triterpene glycosides from two Caribbean sponges. Oecologia 131: 125-136

Kupchan SM, Britton RW, Lacadie JA, Ziegler MF, Sigel CW (1975) The isolation and structural elucidation of bruceantin and bruceantinol. J Org Chem 40:648-654

Lindquist N, Hay ME (1996) Palatability and chemical defense of marine larvae. Ecol Monogr 66:431-450

McClintock J, Baker W (eds) (2001) Marine chemical ecology. CRC Press, Boca Raton, FL

McClintock JB, Swenson DP, Steinberg DK, Michaels AA (1996) Feeding-deterrent properties of common oceanic holoplankton from Bermudian waters. Limnol Oceanogr 41:798-801

O'Neal W, Pawlik JR (2002) A reappraisal of the chemical and physical defenses of Caribbean gorgonian corals against predatory fishes. Mar Ecol Prog Ser 240:117-126

Paul VJ (1992) Chemical defenses of benthic marine invertebrates. In: Paul VJ (ed) Ecological roles of marine natural products. Cornell University Press, Ithaca, NY, p 164-188

Paul VJ, Cruz-Rivera E, Thacker RW (2001) Chemical mediation of macroalgal-herbivore interactions: ecological and evolutionary perspectives. In: McClintock JB, Baker BJ (eds) Marine chemical ecology. CRC Press, Boca Raton, FL, p 227-266

Pawlik JR (1993) Marine invertebrate chemical defenses. Chem Rev 93:1911-1922

Pawlik JR, Chanas B, Toonen RJ, Fenical W (1995) Defenses of Caribbean sponges against predatory reef fish. I. Chemical deterrency. Mar Ecol Prog Ser 127:183-194

Pisut DP, Pawlik JR (2002) Anti-predatory chemical defenses of ascidians: secondary metabolites or inorganic acids? J Exp Mar Biol Ecol 270:203-214

Virnstein RW (1977) The importance of predation by crabs and fishes on benthic infauna in Chesapeake Bay. Ecology 58:1199-1217

Virnstein RW (1979) Predation on estuarine infauna: response patterns of component species. Estuaries 2:69-86

Woodin SA, Walla MD, Lincoln DE (1987) Occurrence of brominated compounds in soft-bottom benthic organisms. J Exp Mar Biol Ecol 107:209-217

Woodin SA, Lindsay SM, Lincoln DE (1997) Biogenic bromophenols as negative recruitment cues. Mar Ecol Prog Ser 157:303-306

Yoon KS, Chen YP, Lovell CR, Lincoln DE, Knapp LW, Woodin SA (1994) Localization of the chloroperoxidase of the capitellid polychaete Notomastus lobatus. Biol Bull (Woods Hole) 187:215-225

Submitted: April 2, 2003; Accepted: August 4, 2003

Proofs received from author(s): November 3, 2003 